\title{
ANALYZING THE USES OF DIFFERENT BRAND MANAGEMENT STRATEGIES OF BANK: A STUDY ON PUBLIC BANK
}

\author{
Shamim Fakir \\ Master of Business Administration \\ Department of Marketing \\ Bangabandhu Sheikh Mujibur Rahman Science \& Technology University \\ Gopalgonj-8100, Bangladesh \\ E-mail: shimimfakir185@gmail.com \\ Abdullah Al Naeem \\ Master of Business Administration \\ Department of Marketing \\ Bangabandhu Sheikh Mujibur Rahman Science \& Technology University \\ Gopalgonj-8100, Bangladesh \\ E-mail: naeem.mkt88@gmail.com \\ Syed Manzurul Karim \\ Master of Business Administration \\ Department of Marketing \\ Bangabandhu Sheikh Mujibur Rahman Science \& Technology University \\ Gopalgonj-8100, Bangladesh \\ E-mail: syedmanzu@gmail.com
}

Received: October 24, $2021 \quad$ Accepted: November 12, $2021 \quad$ Online Published: December 31, 2021

DOI: $10.46281 / a m f b r . v 6 i 1.1626$

URL: https://doi.org/10.46281/amfbr.v6i1.1626

\begin{abstract}
Brand management strategies are a series of techniques used to increase the perceived value of a product or service. Brand management strategies are a series of techniques used to increase the perceived values of all products or services. The objective of the report is to analyze the uses of different brand management strategies of a public bank in Bangladesh. The paper is more important for marketers to know the significance of the uses of different brand management strategies of the public banks. This paper is most significant for the executives to gain a lot of customers by the use of brand management strategies. This is descriptive when the data is analyzed through a structured questionnaire and it is exploratory when the data is analyzed through in-depth interviews. This study is quantitative and qualitative in nature. The quantitative strategy will be utilized on account of the potential for speculation of discoveries. The targeted population of this study was the clients of public banking in Bangladesh. Data was collected
\end{abstract}


using depth interview questionnaire and survey questionnaire. Data were analyzed quantitatively using SPSS, which was a statistical method for analyzing numerical data. The researcher distributed the questionnaires to 50 executives and employees of the public bank who has been asked through questionnaire and non-probability judgmental sampling was taken from an indepth interviews $w$ with the customers and also use the survey questionnaire to the 100 customers.

Keywords: Brand Management, Public Bank, Emotional Connection.

\section{JEL Classification Codes: M38.}

\section{INTRODUCTION}

Brand management strategies are a series of techniques used to increase the perceived value of a product or service. That helps to increase of organization's brand equity, brand recognition \& brand loyalty. Banks don't manufacture products or natural resources from the earth but they sell financial services like providing different types of loans, checking accounts, credit card services, and individual retirement accounts. Bank industries play a crucial role to develop the economy of any country (Karim, 2020; Latif et al., 2019; Karim et al., 2015; Karim et al., 2014; Rehman et al., 2014; Asheq et al., 2021; Tu et al., 2021; Akther et al., 2021; Akhter et., 2020; Islam, 2017). Brands are significant resources for an organization. Brand management strategies are a series of techniques used to increase the perceived values of all products or services. Brand value is the differential impact that realizing the brand name has on client reaction to the item or it's showcasing (Aaker, 1996). The methods of brand management strategies are to promote their products to the market helps to increase brand equity, brand recognition \& brand loyalty. The brand is a name or symbol that represents a product. Brand management is a branding component that involves maintaining and bettering products, services and brand perception. Brand management, when practiced correctly, gives cost leverage, increases customer loyalty and establishes meaningful brand awareness. The paper is more important for marketers to know the significance of the uses of different brand management strategies of bank: a study on public bank in Bangladesh context. At present, competition is high in the market. So, if a company want to position on the customer mind than they have to follow some unique or crucial strategy in business. That's why marketers know about the uses of different brand management strategies of a bank. Brands are important resources for an organization (Ara et al., 2015; Ali et al., 2021; Ali et al., 2020; Baqir et al., 2020; Batool et al., 2021; Islam \& Barghouthi, 2017; Islam et al., 2014; Islam \& Miajee, 2018; Islam, 2016a; Islam, 2016b; Islam, 2016c; Islam et al., 2015; Hossain et al., 2017; Islam, 2015; Islam \& Barghouthi, 2017; Islam et al., 2021). So finally, this paper is most significant for the executives to gain a lots of customers by the uses of brand management strategies .The objective of this study to analyze the uses of different brand management strategies of Rupali Bank. Some scarce reseach has been conducted on brand management in banking sector especially in public bank in Bangladesh.

\section{LITERATURE REVIEW}

Market orientation puts the customer at the center of the overall activities of the organization and is regarded as a pivotal factor in securing and maintaining market leadership in today's competitive environment (Pulendran et al., 2000). Besides, Brand management strategies are marketing strategies giving marketers a new option how to differentiate through surprise and diffusion effect from the other services (France et al., 2018). On the other hand, a brand image is 
a mental image that reflects the way a brand is perceived, including all the identifying elements, the product or company personality, and the emotions and associations evoked in the consumer's mind (Porter, 1985). It can be defined as a unique bundle of associations within the minds of target customers. Brand management helps to create intention among the customers to adopt banking services (Latif et al., 2021). Customer satisfaction basically depends on the brand image of the organization (Karim et al., 2021; Hasan \& Islam, 2020). Positive employees' perceptions of brand identity and its management lead to stronger bonds with the organization and a greater sense of pride and belonging to the firm (Dukerich et al., 2002). Previous studies describe that, higher levels of employees' brand knowledge and a deeper understanding of brand strategies and decisions, as well as the brand values and promises (King \& Grace 2010). Specifically, previous internal branding literature has demonstrated the positive link between some of the dimensions that underlie the Brand image construct and employees' commitment (Burmann et al., 2009). According to McDonald et al. (2001), as well as providing an interrelated and comprehensive network of consumer perceptions, the brand also plays an important behavior a central focus for all employees. Organizations, according to Harris and de Chernatony (2001), need to clearly communicate the brand's purpose to employees to inspire and assist them to understand their role in relation to the brand. In other words, the brand message needs to be conveyed internally so that employee behavior is guided.

\section{METHODOLOGY}

The objective of research suggests that the paper is both qualitative and quantitative in nature. A quantitative study is one that uses interviews to gather data, whereas a more structured study is one that uses a questionnaire. The targeted population of this study was bank clients of public bank in Bangladesh.

Table 1. Gender status of respondents

\section{RESULTS \& DISCUSSION}

\begin{tabular}{|c|c|c|}
\hline Name & Frequency & Percent \\
\hline Male & $\mathbf{5 5}$ & $\mathbf{5 5 . 0}$ \\
\hline Female & $\mathbf{4 5}$ & $\mathbf{4 5 . 0}$ \\
\hline Total & $\mathbf{1 0 0}$ & $\mathbf{1 0 0 . 0}$ \\
\hline
\end{tabular}

The table at above shows that $55.00 \%(\mathrm{n}=55)$ of the respondents are male and the rest $45.00 \%(n=45)$ of the respondents are female.

Table 2. An organization largely depends on its ability to attract consumers towards its brands.

\begin{tabular}{|c|c|c|}
\hline & Frequency & Percent \\
\hline Strongly Agree & $\mathbf{4 7}$ & $\mathbf{4 7 . 0}$ \\
\hline Agree & $\mathbf{3 8}$ & $\mathbf{3 8 . 0}$ \\
\hline Neutral & $\mathbf{7}$ & $\mathbf{7 . 0}$ \\
\hline Disagree & $\mathbf{3}$ & $\mathbf{3 . 0}$ \\
\hline Strongly Disagree & $\mathbf{5}$ & $\mathbf{5 . 0}$ \\
\hline Total & $\mathbf{1 0 0}$ & $\mathbf{1 0 0 . 0}$ \\
\hline
\end{tabular}

This table above shows that $47 \%(n=47)$ of the respondents strongly agreed and 38 $\%(n=38)$ of the respondents are agreed that an organization largely depends on its ability to 
attract consumers towards its brands than other advertising strategy because it can grasp customer attention than other marketing strategy. By the information of this table, this is the evidence that an organization largely depends on its ability to attract consumers towards its brands.

Table 3. Strong brand management strategies in case of better services to attract customers.

\begin{tabular}{|c|c|c|}
\hline & Frequency & Percent \\
\hline Strongly Agree & $\mathbf{3 6}$ & $\mathbf{3 6 . 0}$ \\
\hline Agree & $\mathbf{4 3}$ & $\mathbf{4 3 . 0}$ \\
\hline Neutral & $\mathbf{1 3}$ & $\mathbf{1 3 . 0}$ \\
\hline Disagree & $\mathbf{5}$ & $\mathbf{5 . 0}$ \\
\hline Strongly Disagree & $\mathbf{3}$ & $\mathbf{3 . 0}$ \\
\hline Total & $\mathbf{1 0 0}$ & $\mathbf{1 0 0 . 0}$ \\
\hline
\end{tabular}

This table above shows that $36 \%(n=36)$ of the respondents strongly agreed and also $43 \%$ $(n=43)$ of the respondents agreed that using strong brand management strategies in case of better services to attract customers than another strategy because it can grasp customer attention than another marketing strategy. By the information of this table, this is the evidence that strong brand management strategies in case of better services to attract customers.

Table 4. Public Bank assures better services that create an emotional connection between the brand and its customers.

\begin{tabular}{|c|c|c|}
\hline & Frequency & Percent \\
\hline Strongly Agree & 35 & $\mathbf{3 5 . 0}$ \\
\hline Agree & $\mathbf{2 9}$ & $\mathbf{2 9 . 0}$ \\
\hline Neutral & $\mathbf{2 8}$ & $\mathbf{2 8 . 0}$ \\
\hline Disagree & $\mathbf{4}$ & $\mathbf{4 . 0}$ \\
\hline Strongly Disagree & $\mathbf{4}$ & $\mathbf{4 . 0}$ \\
\hline Total & $\mathbf{1 0 0}$ & $\mathbf{1 0 0 . 0}$ \\
\hline
\end{tabular}

This table above shows that $35 \%(n=35)$ of the respondents strongly agreed and also $29 \%$ $(n=29)$ of the respondents agreed that better services that create an emotional connection between the brand and its customers than other marketing strategy because it can grasp customer attention. By the information of this table, this is the evidence that public banks assures better services that create an emotional connection between the brand and its customers is beneficial.

Table 5. Customer loyalty play a vital role as a brand management strategies in my bank

\begin{tabular}{|c|c|c|}
\hline & Frequency & Percent \\
\hline Strongly Agree & $\mathbf{5 4}$ & $\mathbf{5 4 . 0}$ \\
\hline Strongly Agree & $\mathbf{4 2}$ & $\mathbf{4 2 . 0}$ \\
\hline Agree & $\mathbf{4 1}$ & $\mathbf{4 1 . 0}$ \\
\hline Neutral & $\mathbf{1 0}$ & $\mathbf{1 0 . 0}$ \\
\hline Disagree & $\mathbf{3}$ & $\mathbf{3 . 0}$ \\
\hline Strongly Disagree & $\mathbf{4}$ & $\mathbf{4 . 0}$ \\
\hline
\end{tabular}


This table above shows that $42.0 \%(n=42)$ of the respondents strongly agreed and also $41.0 \%(n=41)$ of the respondents agreed that Customer loyalty play a vital role as a brand management strategies in my bank. By the information of this table, this is the evidence that Customer loyalty play a vital role as a brand management strategies in my bank.

Table 6. Public banks' services for customers shape it as a unique brand from other banks

\begin{tabular}{|c|c|c|}
\hline & Frequency & Percent \\
\hline Strongly Agree & $\mathbf{3 3}$ & $\mathbf{3 3 . 0}$ \\
\hline Agree & $\mathbf{4 7}$ & $\mathbf{4 7 . 0}$ \\
\hline Neutral & $\mathbf{1 0}$ & $\mathbf{1 0 . 0}$ \\
\hline Disagree & $\mathbf{8}$ & $\mathbf{8 . 0}$ \\
\hline Strongly Disagree & $\mathbf{2}$ & $\mathbf{2 . 0}$ \\
\hline Total & $\mathbf{1 0 0}$ & $\mathbf{1 0 0 . 0}$ \\
\hline
\end{tabular}

This table above shows that $33.0 \%(n=33)$ of the respondents strongly agreed and also $47.0 \%(n=47)$ of the respondents agreed that public banks services for customers shape it as a unique brand from other banks. By the information of this table, this is the evidence that public banks services for customers shape it as a unique brand from other banks.

Table 7. Sure-cash is a brand extension of public banks'

\begin{tabular}{|c|c|c|}
\hline & Frequency & Percent \\
\hline Strongly Agree & 37 & $\mathbf{3 7 . 0}$ \\
\hline Agree & $\mathbf{3 8}$ & $\mathbf{3 8 . 0}$ \\
\hline Neutral & $\mathbf{1 8}$ & $\mathbf{1 8 . 0}$ \\
\hline Disagree & $\mathbf{4}$ & $\mathbf{4 . 0}$ \\
\hline Strongly Disagree & $\mathbf{3}$ & $\mathbf{3 . 0}$ \\
\hline Total & $\mathbf{1 0 0}$ & $\mathbf{1 0 0 . 0}$ \\
\hline
\end{tabular}

This table above shows that $37.0 \%(n=37)$ of the respondents strongly agreed and also $38.0 \%(n=38)$ of the respondents agreed that Sure-cash is a brand extension of public banks. By the information of this table, this is the evidence that Sure-cash is a brand extension of public banks'.

Table 8. Customers are more satisfied because they are loyal to public banks.

\begin{tabular}{|c|c|c|}
\hline & Frequency & Percent \\
\hline Strongly Agree & 41 & 41.0 \\
\hline Agree & 39 & $\mathbf{3 9 . 0}$ \\
\hline Neutral & 12 & $\mathbf{1 2 . 0}$ \\
\hline Disagree & $\mathbf{5}$ & $\mathbf{5 . 0}$ \\
\hline Strongly Disagree & $\mathbf{3}$ & $\mathbf{3 . 0}$ \\
\hline Total & $\mathbf{1 0 0}$ & $\mathbf{1 0 0 . 0}$ \\
\hline
\end{tabular}


This table above shows that $41.0 \%(\mathrm{n}=41)$ of the respondents strongly agreed and also $39.0 \%(n=39)$ of the respondents agreed that customers are more satisfied because they are loyal to public banks' brands than others because in that way banks can easily promote products within a very low cost and also can reach within a big range of target customer. By the information of this table, this is the evidence that customers are more satisfied because they are loyal to public banks

\section{DISCUSSION}

At present, Brand Management Strategies have come to play a more important role. Every bank has its own Brand Management Strategies. The report tried to analyze the Uses of Different Brand Management Strategies of public banks and also tried to recommend some guidelines for executives who implement the strategies. Based on findings the primary objective of the report is to analyze the uses of different brand management strategies of the public. Through observational research method the researcher found that brand management strategies in Bangladesh is not new and but some terms are totally new and some banking company is used brand management strategies effectively. According to the findings, it can say that an organization largely depends on its ability to attract consumers towards its brands because it can easily grasp customer's attention and increase brand equity, brand recognition \& brand equity as well as brand image. Most of the customers \& executives express their opinion that an organization largely depends on its ability to attract consumers towards its brands. Maximum Bankers did know about analyzing the uses of different brand management strategies of public banks in Bangladesh. There are very few people who knew about analyzing the uses of different brand management strategies of public banks. Most of the respondent said that "Brand management strategies are a series of techniques used to increase the perceived value of a product or service. $80 \%$ respondent of bank executives said that brand extension impact with the parent brand they said that Brand Extension is the practice of a well-known brand name in new product classes (Zohaib et al., 2021; Tu et al., 2021; Rahaman et al., 2021). They think that brand extension is a significant concern in the feat of a brand and if not done accurately, can cause serious impairment to the brand being extended. But other $20 \%$ of the respondents said that brand extension is depending on the fitness of parent complete and extended brand. If new brand is on the point of the present brand, then there's tons of chances that new product is also selfmade and survive. If new product is at distance of the parent brand, then the probabilities of failure are inflated (Rahaman et al., 2021). More than $80 \%$ of firms resort to brand extensions as a way of marketing goods and services. When firms develop brands under the name of the parent brand the marketers believe that the consumers evaluate brand extensions as favorable because the consumers transfer their positive attitude or effect to the extension made. Overall $60 \%$ of the executives who are said that make a strong brand management strategies are possible through some stages that is Brand positioning, Implementation of brand Marketing, Measuring brand performance and the brand value. On the other hand, (Rahaman et al., 2021) other 35\% of the respondents means that making a strong brand management strategies needed some strategies that is Consider overall business strategy, target clients, target client group, develop your brand positioning, develop messaging strategy, develop name, logo and tagline, develop marketing strategy, implement .The rest $5 \%$ does know not how to make a strong brand management strategies. Almost $70 \%$ executives who faced brand management strategies, said that brand management strategies are interesting (Rahaman et al., 2021). But 20\% executives who faced brand management strategies, said that brand management strategies are not only helps boost the 
value of a product but also build positive customer interaction and think about customer sentiment. It helps to (Rahaman et al., 2021) Differentiation from competitors and consistency of all communications are important factors in successfully building and maintaining brand management strategies (Rahaman et al., 2021). The rest $10 \%$ executives are neural about brand management strategies because they said that sometime brand management strategies are interesting and sometimes not. 85\% executives said yes to this question. They said (Rahaman et al., 2021) that brand is another marketing strategy much effective for any organization as well as public banks in Bangladesh. But the rest $15 \%$ said that sometimes it may not be effective. As indicated by them, brand management strategies can empower undeniable degrees of client mindfulness, commitment and maintenance, which converts into huge authoritative worth.

\section{CONCLUSION}

From the study it can also said that most of the people of Bangladesh have now tend to see something which is brand management strategies. If it will used in banking goods that will be really benefited for the people \& organization. So, the uses of brand management strategies in banking goods have potentiality and some banking organizations already used to with this strategy because it can easily attract customer's attention, and increase brand equity, brand recognition \& brand loyalty. Most of the customer didn't know how the company uses brand management strategies with them to promote or position their products. This report helps the customer and also the bank executives to understand the brand management strategies. Basically, brand management is a series of techniques used to increase the perceived value of a product or service. Overall, brand management strategies is promoting product and the uses of brand management strategies are successfully attracting the customer's attention, and increase brand equity, brand recognition \& brand loyalty.

\section{AUTHOR CONTRIBUTIONS}

Conceptualization: Shamim Fakir, Abdullah Al Naeem, Syed Manzurul Karim

Formal Analysis: Shamim Fakir, Abdullah Al Naeem, Syed Manzurul Karim

Funding Acquisition: Shamim Fakir, Abdullah Al Naeem, Syed Manzurul Karim

Investigation: Shamim Fakir, Abdullah Al Naeem, Syed Manzurul Karim

Methodology: Shamim Fakir

Project Administration: Shamim Fakir, Abdullah Al Naeem

Resources: Shamim Fakir, Abdullah Al Naeem, Syed Manzurul Karim

Software: Shamim Fakir, Syed Manzurul Karim

Supervision: Shamim Fakir, Abdullah Al Naeem, Syed Manzurul Karim

Validation: Shamim Fakir, Abdullah Al Naeem, Syed Manzurul Karim

Visualization: Shamim Fakir, Abdullah Al Naeem, Syed Manzurul Karim

Writing - Original Draft: Shamim Fakir, Abdullah Al Naeem, Syed Manzurul Karim

Writing - Review \& Editing: Shamim Fakir, Abdullah Al Naeem, Syed Manzurul Karim

\section{CONFLICT OF INTEREST STATEMENT}

The authors declare that they have no competing interests.

\section{ACKNOWLEDGEMENT}

All authors contributed equally to the conception and design of the study. 


\section{REFERENCES}

Ali, M. C., Islam, K. M. A., Chung, S. J., Zayed, N. M., \& Islam, M. R. (2021). The Correlation between Job-Hopping Attitude and Turnover Behavior: A Job Satisfaction Perspective in Bangladesh. International Journal of Business and Management Future, 5(1), 14-26.

Ali, M. C., Islam, K. M. A., Chung, S. J., Zayed, N. M., \& Afrin, M. (2020). A Study of Green Human Resources Management (GHRM) and Green Creativity for Human Resources Professionals. International Journal of Business and Management Future, 4(2), 57-67.

Alhassan, I., Islam, K. M. A., \& Haque, M. S. (2021). Sustainability Reporting and Financial Performance of Listed Industrial Goods Sector in Nigeria. International Journal of Accounting \& Finance Review, 9(1), 46-56.

Ali, A.R.S.I., \& Dahana, W.D. (2021). What inhibits consumers in emerging countries from engaging in status consumption? A latent class conjoint analysis approach. International Journal of Emerging Markets. https://doi.org/10.1108/IJOEM-02-2021-0223

Al Amin, M., Arefin, M. S., Sultana, N., Islam, M. R., Jahan, I., \& Akhter, A. (2020). Evaluating the customers' dining attitudes, e-satisfaction and continuance intention toward mobile food ordering apps (MFOAs): evidence from Bangladesh. European Journal of Management and Business Economics, 30(2), 211-229. https://doi.org/10.1108/EJMBE-04-2020-0066

Akhter, A., Karim, M. K., \& Islam, A. K. (2021). The impact of emotional intelligence, employee empowerment and cultural intelligence on commercial bank employees' job satisfaction. Banks and Bank Systems, 16(4), 11-21.

Akhter, A., Asheq, A. A., Hossain, M. U. \& Karim, M. K. (2020). Exploring customer intentions to adopt mobile banking services: evidence from a developing country. Banks and Bank Systems, 15(2), 105-116. http://dx.doi.org/10.21511/bbs.15(2).2020.10

Akhter, A., Asheq, A. A., Hossain, M. U., \& Karim, M. K. (2020b). Exploring customer intentions to adopt mobile banking services: Evidence from a developing country. Banks and Bank Systems, 15(2), 105-116.

Ara, E., Akhter, A., \& Hoque, M. A. (2015). Analyzing the Changes of Preference Factors of Billboard by the Gender, Age \& Occupation of Customer: A Study on Dhaka City. AIUB Journal of Business and Economics, 12(1), 81-100.

Asheq, A.A., Tanchi, K.R., Kamruzzaman, M., \& Karim, M.M. (2021). The impact of emarketing orientation, technological orientation, and learning capacity on online SME performance. Innovative Marketing, 17(3), 168-179.

Baqir, M., Hussain, S., Waseem, R., \& Islam, K. M. A., (2020). Impact of Reward and Recognition, Supervisor Support on Employee Engagement. American International Journal of Business and Management Studies, 2(3), 8-21. 
Batool, N., Hussain, S., Baqir, M., Islam, K. M. A., \& Hanif, M. (2021). Role of HR Technology and Training for the Development of Employees. International Journal of Business and Management Future, 5(1), 1-13.

Burmann, C., Zeplin, S., Riley, N. (2009). Key determinants of internal brand management success: an exploratory empirical analysis, Journal of Brand Management 16(4), 264284. https://doi.org/10.1057/bm.2008.6

Donald, M., de Chernatony, L., \& Harris, F. (2001). "Corporate marketing and service brands moving beyond the fast moving consumer goods model", European Journal of Marketing, 35(3/4), 335-52.

Dukerich, J. M., Golden, B. R., \& Shortell, S. M. (2002). Beauty is in the eye of the beholder: the impact of organisational identification, identity, and image on the cooperative behaviors of physicians. Administrative Science Quarterly 47, 507-533. https://doi.org/10.2307/30948

France, C., Grace, D., Merrilees, B., \& Miller, D. (2018). Customer brand co-creation behavior: conceptualization and empirical validation. Marketing Intelligence \& Planning.

Islam, K. M. A., \& Barghouthi, O. A. (2017). Risk Management of Islamic Banking: An Islamic Perspective. International Journal of Islamic Banking and Finance Research, 1(1), 2528.

Islam, K. M. A., \& Miajee, M. R. K. (2018). Small and Medium Enterprises (SMEs) Financing in Bangladesh: A Review of Literature. International Journal of Small and Medium Enterprises, 1(1), 11-15.

Islam, K. M. A. (2016a). Financial Performance Comparison of Top Rated Banking Financial Institutions (BFIs) of Bangladesh. Indian Journal of Science, 23(85), 669-697.

Islam, K. M. A. (2016b). Factors influencing consumers purchase decision: a case study of Pantene shampoo. Indian Journal of Science, 23(88), 910-923.

Islam, K. M. A. (2016c). Corporate Governance: Conjecture and Modernism. Indian Journal of Science, 23(86), 798-817.

Islam, K. M. A., Alam, I., \& Al-Amin, D. M. (2015). Foreign exchange operation of private commercial banks in Bangladesh: A case study on AB Bank Limited. International Journal of Innovative Research and Creative Technology, 1(3). 296-304.

Islam, K. M. A. (2015). Throughput accounting: a case study. International Journal of Finance and Banking Research, 1(2), 19-23. 
Islam, K. M. A., Alam, I., \& Hossain, S. A. (2014). Examination of profitability between Islamic banks and conventional banks in Bangladesh: A comparative study. Research in Business and Management, 1(1), 78-89.

Islam, K. M. A., \& Barghouthi, O. A. (2017). Risk Management of Islamic Banking: An Islamic Perspective. International Journal of Islamic Banking and Finance Research, 1(1), 2528.

Islam, K. M. A., Sadekin, M. S., Rahman, M., Chowdhury, M., \& Haque, A. (2021). The impact of Shariah supervisory board and Shariah audit committee on CSR adoption at Islamic banks. Journal of Asian Finance, Economics and Business (JAFEB), 8(3), 479-485.

Islam, K. A. (2017). An Empirical Research on Fu-Wang Foods Ltd: Industry, Strategy, Accounting, Ratio, Valuation and Proforma Analysis. American Finance \& Banking Review, 1(1), 1-11.

Hossain, S. A., Islam, M. N., Mahmud, M. S., \& Islam, K. M. A. (2017). Evaluation of Financial Performance of Commercial Banks in Bangladesh: Comparative Study Based on CAMEL Approach. The Millennium University Journal, 2(1), 54-77.

Hasan, Z., \& Islam, K. A. (2020). Academic, Financial and Administrative Issues of Online Teaching during Corona Pandemic: The Scenario of Private Universities in Bangladesh. International Journal of Accounting \& Finance Review, 5(1), 116-122.

Hossain, M. U. (2021). Relationship between Individual Characteristics and Social Entrepreneurial Intention: Evidence from Bangladesh. Business and Economics Research Journal, 12(2), 385-397.

Hossain, M. U., Arefin, M. S., \& Yukongdi, V. (2021). Personality Traits, Social Self-Efficacy, Social Support, and Social Entrepreneurial Intention: The Moderating Role of Gender. Journal of Social Entrepreneurship, 1-21.

Karim, M., Islam, J., \& Mahmud, L. (2014). Job Satisfaction of Employees in Banking Sector. A Case Study on Janata Bank Limited. European Journal of Business and Management, 6(17), 70-78.

Karim, M. M., Bhuiyan, M. Y. A., Nath, S. K. D., \& Latif, W. B. (2021). Conceptual Framework of Recruitment and Selection Process. International Journal of Business and Social Research, 11(02), 18-25. https://doi.org/10.18533/ijbsr.v11i02.1415

Karim, M., Haque, M, Dona, P.D, Moniruzzaman, M. (2015) .Performance Appraisal System of Employees of Private Banking Sector in Bangladesh. A Case Study on National Bank Limited. International Journal of Advanced Multidisciplinary Research, 2(3), 1-5. 
Karim, M., Islam, J., \& Mahmud, L. (2014). Job Satisfaction of Employees in Banking Sector. A Case Study on Janata Bank Limited. European Journal of Business and Management, 6(17), 70-78.

King, C., Grace, D. 2012. Examining the antecedents of positive employee brand-related attitudes and behaviours, European Journal of Marketing 46(3/4), 469-488. https://doi.org/10.1108/03090561211202567

Kurawa, J. M., Alhassan, I., Islam, K. M. A., \& Haque, M. S. (2021). Ownership Structure and Financial Reporting Quality in Listed Non-Financial Firms in Nigeria. International Journal of Accounting \& Finance Review, 9(1), 57-73.

Latif, W. B., Pervin, K., \& Karim, M. (2021). The Impact of the Fourth Industrial Age (I4. 0) On Higher Education (He4. 0): In the Perspective of Bangladesh. International Journal of Education and Social Science Research, 4(5) http://dx.doi.org/10.37500/IJESSR.2021.4501

Latif, W.B., \& Karim, M.M. (2019). The art of developing entrepreneurial leadership. International Journal of Research in Management, 1(1), 18-21.

McDonald, M., de Chernatony, L., \& Harris, F. (2001). Corporate marketing and service brands - moving beyond the fast moving consumer goods model", European Journal of Marketing, 35(3/4), 335-52.

Porter M. (1985). Competitive Advantage, New York, Free Press.

Pulendran, S., Speed, R., \& Widing, R. (2000). The antecedents and consequences of market orientation in Australia", Australian Journal of Management, 25(2), 119-44.

Rahaman, M. A., Luna, K. F., Ping, Z. L., Islam, M. S., \& Karim, M. M. (2021). Do RiskTaking, Innovativeness, and Proactivity Affect Business Performance of SMEs? A Case Study in Bangladesh. The Journal of Asian Finance, Economics, and Business, 8(5), 689695.

Rahaman, M. A., Ali, M. J., Kejing, Z., Taru, R. D., \& Mamoon, Z. R. (2020). Investigating the effect of service quality on bank customers' satisfaction in Bangladesh. The Journal of Asian Finance, Economics, and Business, 7(10), 823-829.

Rahaman, M. A., Luna, K. F., Ping, Z. L., Islam, M. S., \& Karim, M. M. (2021). Do RiskTaking, Innovativeness, and Proactivity Affect Business Performance of SMEs? A Case Study in Bangladesh. The Journal of Asian Finance, Economics and Business, 8(5), 689695.

Rahaman, M. K., Gazi, M. A. I., Bhuiyan, M. A., \& Rahaman, M. A. (2021). Effect of Covid-19 pandemic on tourist travel risk and management perceptions. Plos one, 16(9), e0256486. 
Rahaman, M. A., Ali, M. J., Wafik, H., Mamoon, Z. R., \& Islam, M. M. (2020). What Factors Do Motivate Employees at the Workplace? Evidence from Service Organizations. The Journal of Asian Finance, Economics, and Business, 7(12), 515-521.

Rahaman, M. A., Luna, K. F., Mite, S., Islam, M., \& Wafik, H. (2021). The effect of entrepreneurial orientation, market orientation and gender on business performance: An empirical study of SMEs in Bangladesh. The Journal of Asian Finance, Economics and Business, 8(6), 741-746.

Rahaman, M. A., Gupta, A., Ali, A. I., Ali, M. J., \& Taru, R. D. (2021). Identification of Determining Factors of Employee Performance of SME Business. Academy of Entrepreneurship Journal, 27(6), 1-5.

Rehman, F. U., Ilyas, M., Nawaz, T., \& Hyder, S. (2014). How Facebook advertising affects the buying behavior of young consumers: The moderating role of gender. Academic Research International, 5(4), 395-404.

Tu, B., Bhowmik, R., Hasan, M., Asheq, A. A., Rahaman, M., \& Chen, X. (2021). Graduate Students' Behavioral Intention of toward Social Entrepreneurship: Role of Social Vision, Innovativeness, Social Proactiveness, and Risk Taking. Sustainability, 13(11), 6386.

Zohaib, M., Islam, K. M. A., Tahir, M. Y., Hussain, R., Zaineb, A., \& Ismail, M. (2021). The Innovative Financial Product Development with Its Functional Performance. American International Journal of Economics and Finance Research, 3(1), 1-15.

\section{Copyrights}

Copyright for this article is retained by the author(s), with first publication rights granted to the journal. This is an open-access article distributed under the terms and conditions of the Creative Commons Attribution license (https://creativecommons.org/licenses/by/4.0). 